\title{
Efficient Culture of Rhodopseudomonas palustris Using Landfill Leachate
}

\author{
Qing Wang, Lijun Shen, Zhenzhen Zhao, Hai Yan, Qianqian Xu, Chunhua Yin, \\ Xiaolu Liu, Haiyang Zhang and Yang Liu
}

School of Chemistry and Biological Engineering, University of Science and Technology Beijing, Beijing 100 083, P. R. China.

\begin{abstract}
The efficient culture of Rhodopseudomonas palustris using landfill leachate was investigated. Total organic carbon (TOC) and total nitrogen (TN) in landfill leachate were $16.0 \mathrm{~g} / \mathrm{L}$ and $1.1 \mathrm{~g} / \mathrm{L}$ at pH 4.5, respectively, which was apparently reduced with the increase of $\mathrm{pH}$. Compared with carbon or nitrogen source added, the addition of phosphorus could greatly promote the growth of $R$. palustris using landfill leachate as culture medium. Both the growth of $R$. palustris and the removals of TOC and TN were enhanced by increasing inoculation ratios $(\mathrm{v} / \mathrm{v})$ of $R$. palustris from $20 \%$ to $50 \%$ and the highest cell density of $2.0 \times 109 \mathrm{cell} / \mathrm{mL}$ was obtained. The viability and integrity of $R$. palustris was further detected with the fluorometry method of double staining and the highest proportion of $99.4 \%$ live cells was found at $72 \mathrm{~h}$. This study is very important in the efficient utilization of landfill leachate to culture $R$. palustris as bacterial manure.
\end{abstract}

Keywords: Rhodopseudomonas palustris, Landfill leachate, Culture, Living cell.

*Correspondence: haiyan@ustb.edu.cn; +86-010-6233-3177;

(Received: 23 October 2018; accepted: 06 December 2018)

Citation: Qing Wang, Lijun Shen, Zhenzhen Zhao, Hai Yan, Qianqian Xu, Chunhua Yin, Xiaolu Liu, Haiyang Zhang and Yang Liu, Efficient Culture of Rhodopseudomonas palustris Using Landfill Leachate, J Pure Appl Microbiol., 2018; 12(4): 1679-1686. http:// dx.doi.org/10.22207/JPAM.12.4.01

(c) The Author(s) 2018. Open Access. This article is distributed under the terms of the Creative Commons Attribution 4.0 International License which permits unrestricted use, sharing, distribution, and reproduction in any medium, provided you give appropriate credit to the original author(s) and the source, provide a link to the Creative Commons license, and indicate if changes were made. 


\section{INTRODUCTION}

With the accelerating process of urbanization and the rapid improvement of urban people's living standards, large amounts of landfill leachate have been generated with the annual growth rate of $8 \%-10 \%$ and the million tons of wastewater has been discharged into rivers and oceans ${ }^{1}$. Landfill leachate contains large amounts of dissolved organic matter, inorganic macro components, including sulfate, chloride, and ammonia, toxic heavy metals, and toxic xenobiotic organic compounds ${ }^{2}$. Traditional waste disposal methods, including incineration, landfill and mechanical pulverization directly, bring serious consequences to the human ecological environment ${ }^{3}$. Merugu, $\mathrm{R}$ et al. thought purple non-sulphur bacteria could reduce chromium ${ }^{4}$. Kaitlyn D.Sniffen used an algae-based landfill leachate remediation system aims to remove nutrients from liquid waste by nitrogen assimilation into new algal biomass ${ }^{5}$. Therefore, the environmental friendly and efficient technology of high strength wastewater treatment is quite essential ${ }^{6}$. Compared with traditional methods, photosynthetic bacteria (PSB), with its high salt-tolerance and activity, has great potential in treating various high concentration organic wastewater. In addition to pollutant removal, the wastewater treatment with PSB can accumulate valuable biomass as bacterial manure ${ }^{7}$, food coloring agent, precursor of vitamin A in food and animal feed, ${ }^{2}$-carotene and astaxanthin in industry, and additives to porphyrin ${ }^{8,9}$. The extraction source of polyhydroxyalkanoate as biodegradable plastics from PSB was also reported ${ }^{10}$. Recently, increasing demands for products from "organic farming" have encouraged farmers to use bacterial manure instead of chemicals. PSB has been claimed to be essential because of its ability to fix $N 2^{11}$ and to produce plant growth promoter, such as 5-aminolevulinic acid (ALA), indole 3-acetic acid (IAA) (auxins) and cytokinins ${ }^{12,13}$. So the efficient utilization of landfill leachate to culture PSB has attracted great attention.

Rautter et al. proposed the common reaction formula of photosynthesis ${ }^{14}$, explained the biosynthesis phenomenon with biochemical uniformity, and laid a foundation for the research of PSB after its scientific classification and physiological research. Since 1960 s, as a typical bacterial strain of PSB, Rhodopseudomonas palustris has been used to treat diary wastewater, soybean wastewater, food wastewater, fermented starch wastewater and domestic wastewater ${ }^{15,16,17}$. In the process of PSB wastewater treatment, the most important factor is the light-oxygen condition ${ }^{17,18,19}$. The light recipe including light intensity, light source and photoperiod could influence biomass and COD removal in the wastewater treatment ${ }^{7,20,21}$. Some studies have demonstrated that higher DO level achieved higher biodegradation efficiency and lower DO led to poorer bio-flocculating ability and less bound extracellular polymeric substances content of the activated sludge $22,23,24$. Although the treatments of wastewater with PSB were widely investigated, no information is provided on the resource utilization of landfill leachate to culture $R$. palustris effectively as bacterial manure.

The aim of this study is to reuse landfill leachate containing much amount nutrients of protein, sugar, oil and so on as medium to efficiently culture $R$. palustris for fixing nitrogen as bacterial manure. Both the treatment of landfill leachate and the production of $R$. palustris are simultaneously achieved.

\section{MATERIALS AND METHODS Materials}

The bacterial strain of Rhodopseudomonas palustris (No. 1.2180) used in this experiment was bought from the China General Microbiological Culture Collection Center, which was routinely cultivated in our laboratory under outdoor sunlight at the temperature from $20^{\circ} \mathrm{C}$ to $40^{\circ} \mathrm{C}$ for $96 \mathrm{~h}$ as the seed ${ }^{25}$. The landfill leachate derived from the solid filtered liquid of kitchen waste, which was sent by Green Space Biotech Limited Company at Beijing, P.R.China, was used in this study.

\section{Methods}

\section{Detection of physicochemical indexes of landfill} leachate

The contents of $\mathrm{Cr}, \mathrm{Cd}, \mathrm{Cu}, \mathrm{Ni}, \mathrm{Mg}, \mathrm{Zn}$ and $\mathrm{Pb}$ in landfill leachate were tested by ICP optical emission spectrometer (715-ES, varian, United States) and Thermo Scientific (M6, Thermo, United States), respectively. Landfill leachate was diluted 200 times with purified water and filtered through a $0.2 \mu \mathrm{m}$ membrane to measure TOC and TN on a TOC-V (CPH-CPN, Shimadzu, Japan). 
Flocculation of TOC and TN in landfill leachate by increasing $\mathrm{pH}$

Initial pH 4.5 of landfill leachate was gradually increased to $7.0,8.0,9.0,10.0$ by directly adding $1 \mathrm{~mol} / \mathrm{L}$ sodium hydroxide, respectively, and after standing two hours, the supernatant of landfill leachate at $\mathrm{pH} 9$ was used to culture $R$. palustris.

Effects of nutrients added on the growth of Rhodopseudomonas palustris

The supernatant of $1500 \mathrm{~mL}$ landfill leachate at $\mathrm{pH} 9$ was added $3.0 \mathrm{~g} / \mathrm{L}$ sodium acetate as carbon source, $1.0 \mathrm{~g} / \mathrm{L}$ urea as nitrogen source, or $1.0 \mathrm{~g} / \mathrm{L}$ disodium phosphate as phosphorus source, respectively, and then inoculated with 450 $\mathrm{mL}$ of $R$. palustris (v/v, 30\%) prepared and initial $\mathrm{pH}$ was adjusted to 8.0, which was divided into $100 \mathrm{~mL}$ transparent plastic bottle to anaerobic culture $R$. palustris under sunlight outdoor at the temperature from $20^{\circ} \mathrm{C}$ to $40^{\circ} \mathrm{C}$. The samples of culture solution were taken every day to measure optical density at wavelength of $500 \mathrm{~nm}$ (OD500nm) on a spectrophotometer (722s, Chain) to represent biomass of $R$. palustris, pH (PHS-25, Leici, Chain), TOC and TN. The average values of three samples with the standard deviation were indicated in figures.

Measurement of the cell density of Rhodopseudomonas palustris with flow cytometry

A flow cytometer (Partec CY-S-3001, Germany) was used to measure the cell density of $R$. palustris. For a flow cytometer measuring, the gain numeric of handle system parameter was set as follows: FSC 200, SSC 240.

To measure cell density of $R$. palustris, the culture solution of $100 \mu \mathrm{L}$ was taken and diluted with phosphate buffer solution (PBS; $\mathrm{pH}$ 7.0) to 1000 folds, and the sample of $800 \mu \mathrm{L}$ was prepared in a $2 \mathrm{~mL}$ transparent test tubes for the detection of cell density with flow cytometer at the excitation and emission wavelengths of $488 \mathrm{~nm}$ at room temperature. Each sample was pumped at 2 ms-1 for about $1.5 \mathrm{~min}$.

Determination of cell viability of Rhodopseudomonas palustris by dual fluorescence assay

A double-staining fluorescence procedure using fluorescein diacetate (FDA, Sigma- Aldrich) and propidium iodide (PI, Aladdin) was used to determine the cell viability of $R$. palustris. FDA labeled cells are considered as viable cells with effective enzymatic activity, but PI labeled cells are considered as dead cells with compromised membranes. The fluorescence signals were detected in filter channel1 (FL1) and filter channel 2 (FL2), respectively ${ }^{26,27,28}$.

For flow cytometer measuring, the gain numeric of handle system parameter was set as follows: FSC 200, SSC240, FL1 300, FL2 330. 100 mL culture solution of $R$. palustris at $72 \mathrm{~h}$ was taken as fresh cells and $100 \mathrm{~mL}$ fresh cells was heat-killed in a water bath at $80^{\circ} \mathrm{C}$ for $30 \mathrm{~min}$ as dead cells. The mixtures of $100 \mathrm{~mL}$ fresh cells and $100 \mathrm{~mL}$ heat-killed cells was used as the control sample for analyses. Fresh cells were stained with FDA and heat-killed cells were stained with $\mathrm{PI}$, and mixture cells were stained with both PI and FDA.

For analyzing the live cells of $R$. palustris cultured with landfill leachate, $1 \mathrm{~mL}$ of sample was placed into a centrifuge tube and stained with $10 \mu \mathrm{L}$ FDA working solution $(5 \mathrm{mg} / \mathrm{mL})$ and $30 \mu \mathrm{L}$ PI working solution $(1 \mathrm{mg} / \mathrm{mL})$. The stained sample was then incubated in $30^{\circ} \mathrm{C}$ cupboard for 30 minutes in dark and then for the measurement according to the report ${ }^{28}$.

\section{Statistical analysis}

Three repetitions of each experiment were performed and the average values were indicated in figures. Tukey's test was adopted to analyze the significance of data. The level of significance of different groups exceeded 95\% (P $<0.05)$.

\section{RESULTS AND DISCUSSION \\ Characterization of landfill leachate}

The physiochemical properties of landfill leachate used in this experiment are shown in Table 1, which contained a high organic matter including TOC of $16.0 \mathrm{~g} / \mathrm{L}$ and TN of $1.1 \mathrm{~g} / \mathrm{L}$, respectively. The content of $\mathrm{NaCl}$ was $15.2 \mathrm{~g} / \mathrm{L}$ and the various metals such as $\mathrm{Cd}, \mathrm{Cr}, \mathrm{Cu}, \mathrm{Pb}, \mathrm{Ni}$ and $\mathrm{Zn}$ were also found in landfill leachate with low $\mathrm{pH}$ of 4.5 .

Similar to the report by Qin et al. ${ }^{29}$, the landfill leachate from food processing as a high-strength wastewater was rich in organic contaminants, nitrogen, toxic metal and soluble salts with low $\mathrm{pH}$ (Table 1 ). The treatment of landfill leachate is challenging due to the high levels of contaminants including organics, 
Table 1. Physiochemical characteristics of landfill leachate.

\begin{tabular}{lc}
\hline Parameter & Content \\
\hline $\mathrm{TOC}(\mathrm{g} / \mathrm{L})$ & 1.6 \\
$\mathrm{TN}(\mathrm{g} / \mathrm{L})$ & 1.1 \\
$\mathrm{NaCl}(\mathrm{g} / \mathrm{L})$ & 15.2 \\
$\mathrm{Mg}(\mathrm{g} / \mathrm{L})$ & 102 \\
$\mathrm{P}(\mathrm{mg} / \mathrm{L})$ & 300 \\
$\mathrm{Cu}(\mathrm{mg} / \mathrm{L})$ & $\leq 0.1$ \\
$\mathrm{~Pb}(\mathrm{mg} / \mathrm{L})$ & 0.13 \\
$\mathrm{Ni}(\mathrm{mg} / \mathrm{L})$ & 0.12 \\
$\mathrm{Zn}(\mathrm{mg} / \mathrm{L})$ & 0.48 \\
$\mathrm{pH}$ & 4.5 \\
\hline
\end{tabular}

ammonia, inorganic substances, toxic metals and toxic hydrocarbons (aromatic and phenolic compounds) together with the variability in its quantity and quality in both space and time ${ }^{30,31}$.

Effect of $\mathrm{pH}$ on the flocculation of organic compounds in landfill leachate

The changes of TOC and TN in landfill leachate as well as picture at different $\mathrm{pH}$ are shown in Figure 1. The original solution at $\mathrm{pH} 4.5$ was very turbid with little sediment. With the increase of $\mathrm{pH}$ from 7 to 10 respectively, the larger amounts of precipitate was produced (Fig. 1a). TOC and TN in the supernatant of landfill leachate decreased gradually from $16.0 \mathrm{~g} / \mathrm{L}$ and $1.1 \mathrm{~g} / \mathrm{L}$ to $14.8 \mathrm{~g} / \mathrm{L}$ and $0.9 \mathrm{~g} / \mathrm{L}$, respectively (Fig. 1b).

Generally the flocculation was achieved by adding flocculants such as ferric chloride $\left(\mathrm{FeCl}_{3}\right)$ and polyaluminium chloride ${ }^{32}$. Better organic matter removal was observed when leachate was treated with $\mathrm{FeCl}_{3}{ }^{33}$. Here we found that the organic compounds in landfill leachate can be flocculated simply by increasing pH (Fig.1), which was not reported and probably attributed to the electrolytic rate of solution affected by different $\mathrm{pH}^{34}$. Furthermore the removal of TN from landfill leachate might be partly caused by the evaporation of ammonia gas produced by the increase of $\mathrm{pH}$.

Effects of nutrients added on the growth of Rhodopseudomonas palustris

Figure 2 showed the growth of $R$. palustris and $\mathrm{pH}$ of culture solution by adding sodium acetate, urea and disodium phosphate, respectively. Compared with that of control, the growths of $R$. palustris were obviously promoted by adding carbon, nitrogen and especially phosphorus sources, respectively, and the highest OD500nm of 11.3 was obtained at $96 \mathrm{~h}$ (Fig. 2a). The results also indicated that $\mathrm{pH}$ were all gradually increased from 8.0 at $0 \mathrm{~h}$ to more than 9.0 at $96 \mathrm{~h}$ (Fig. $2 b)$. Generally organic acids remained in landfill leachate could be used as carbon source by $R$. palustris, which might cause the increase of $\mathrm{pH}^{35}$. Phosphorus as a nutrient element and stimulating factor of enzyme was found to play an important role in both hydrogen production and the growth of $R$. palustris ${ }^{36}$. Qin et al. also reported that PSB were not taking up the available carbon efficiently in phosphorus-limited condition ${ }^{29}$. Here we indicated that, compared with carbon and nitrogen sources, phosphorus was a most limiting factor in the growth of $R$. palustris using landfill leachate as culture medium (Fig.2a). Furthermore $\mathrm{pH}$ played an important role in the growth of $R$. palustris, which grew in the $\mathrm{pH}$ range from 6.5 to 10.0 , and the appropriate range was from 8.0 to $10.0^{37}$. $\mathrm{pH}$ has an effect on the structure of the
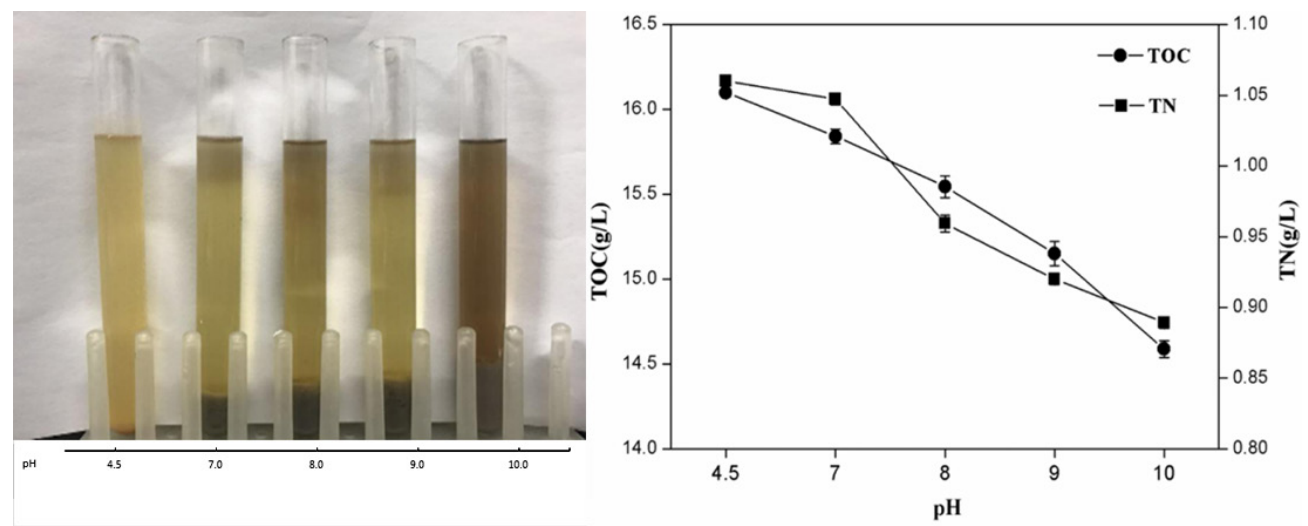

Fig. 1. Removals of TOC and TN from landfill leachate by increasing $\mathrm{pH}$. 


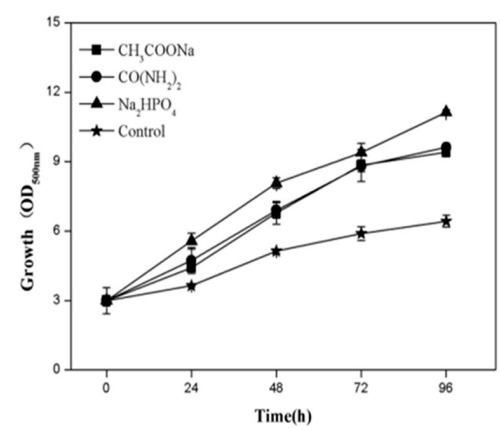

(a)

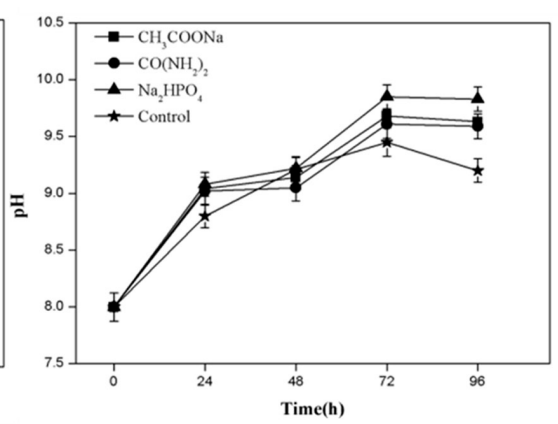

(b)

Fig. 2. Etfects of $\mathrm{CH}_{3} \mathrm{COONaOCO}\left(\mathrm{NH}_{2}\right)_{2}$ and $\mathrm{Na}_{2} \mathrm{HPO}_{4}$ on the growth of $R$. palustris in landfill leachate, growth (a) and $\mathrm{pH}(\mathrm{b})$.

pigment-protein complex and the stability function of the entire cyclic structure. Low $\mathrm{pH}$ induced the deletion of B800 bacterial chlorophyll molecule in the LH2 complex of Rhodobacter capsulatus ${ }^{38}$ and Rhodopseudomonas acidophila ${ }^{39}$. Here we found that the change of $\mathrm{pH}$ range from 8.0 to 10 was suitable to the growth of $R$. palustris using landfill leachate as culture medium (Fig.2b).

Effects of inoculums on the growth of Rhodopseudomonas palustris in landfill leachate

As shown in Fig. 3a, the cell scatter diagram of $R$. palustris (R1) could be clearly shown with ûow cytometer. The cell densities of R. palustris with different inoculums from $20 \%$ to $50 \%(\mathrm{v} / \mathrm{v})$ were all increased with time course in the period of $96 \mathrm{~h}$ and the highest cell density of $2.0 \times 109$ cell $/ \mathrm{mL}$ was obtained with the inoculation proportion of $50 \%$ (Fig. $3 \mathrm{~b}$ ). pH of culture solutions also raised to 9.0 or so with the different inoculums of $R$. palustris at $96 \mathrm{~h}$ (Fig. 3c).

Figure 4 showed that both TOC and TN in culture solution all significantly decreased with the growth of $R$. palustris at the different inoculums during the period of $96 \mathrm{~h}$. With the increase of inoculation proportion of $R$. palustris from $20 \%$ to $50 \%(\mathrm{v} / \mathrm{v})$, both the removal amount and removal ratio of TOC in culture solution enhanced (Fig.4a). Similar to TOC, the reduction of TN was also promoted by increasing inoculation proportion of R. palustris from $20 \%$ to $50 \%$ (v/v) (Fig.4b). With the augment of inoculation proportion, both the growth of $R$. palustris and the removals of TOC and TN were gradually enhanced (Fig.3 and 4).

The inoculation proportion is a very important factor in the rapid growth of $R$. palustris as the dominant bacteria. In the treatment of brewery wastewater by PSB with the inoculation
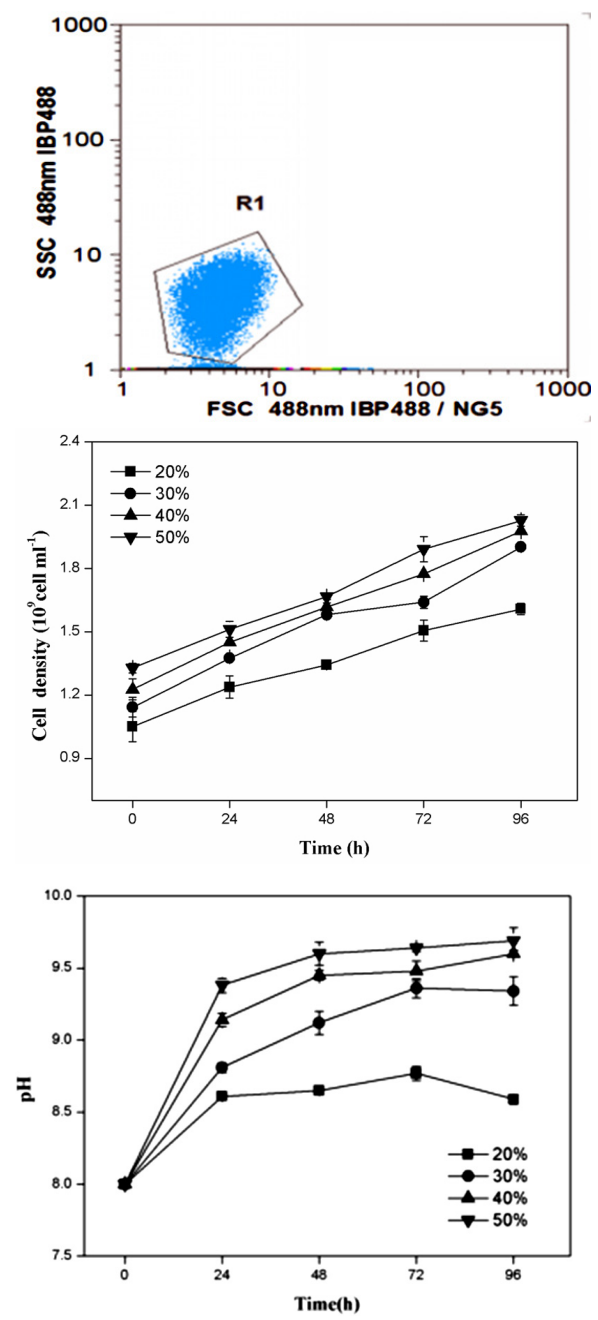

Fig. 3. Effects of the different inoculums on the growth of $R$. palustris in landfill leachate, the cell scatter diagram of $R$. palustris (a), the cell densities of R. palustris (b) and the change of $\mathrm{pH}(\mathrm{c})$. 


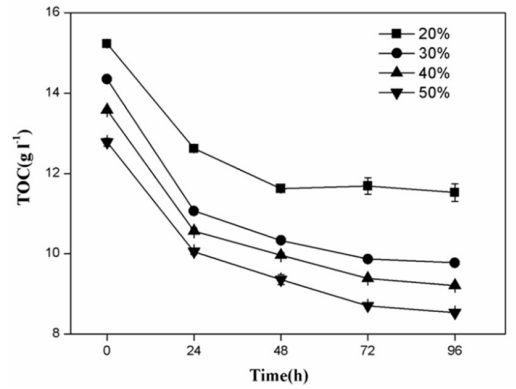

(a)

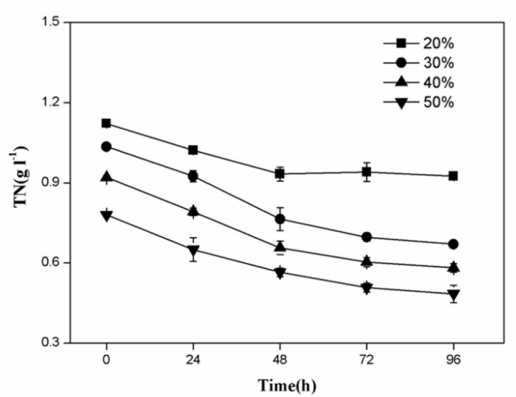

(b)

Fig. 4. Effects of the different inoculums of $R$. palustris on the removals of TOC (a) and TN (b) from landfill leachate. proportion of $10 \%(\mathrm{v} / \mathrm{v})$, PSB were difficult to grow and form dominant bacteria, and the contaminating bacteria and odors are generated. When inoculum proportion was increased, both the growth of PSB and the removal of COD in the treatment of brewery improved ${ }^{40}$. Many studies concentrated on the removals of pollutants by PSB $^{41,42}$, but less information focused on the growth of PSB as bacterial manure, which ignored the resource utilization of landfill lealeachatether. The viability and integrity of Rhodopseudomonas palustris

As shown in Figure 5, more than $99 \%$ of fresh cells (R1) displayed a green fluorescence with a corresponding fluorescence intensity (Fig.5a). In contrast, $98 \%$ of heat-treated cells (R2)

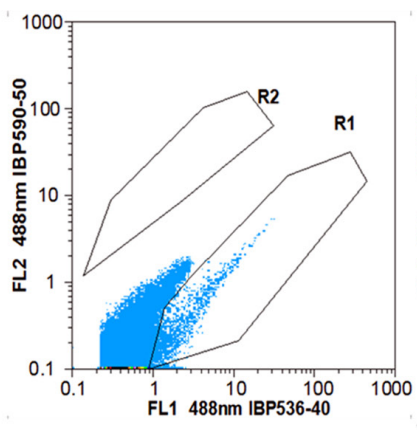

(a)

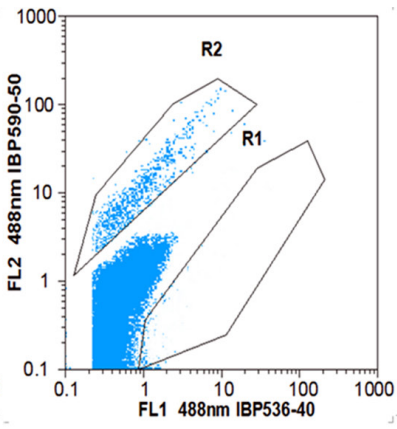

(b)

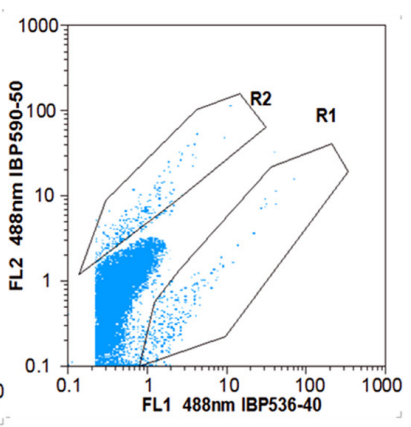

(c)

Fig. 5. Identification of live and dead cells of $R$. palustris with FDA-PI double-fluorescent staining. Dot plots representing carboxyfluorescein (R1) and propidium iodide fluorescent (R2) signals of $R$. palustris. Freshly harvested cells stained with FDA (a) and heat-killed cells were stained with PI(b). Multiparameter dot plot obtained after FDA-PI double staining of freshly harvested cells and heat-killed cells (c).

Many studies focused on the state of lactic acid bacteria with double-fluorescent staining in conjunction with a flow cytometer ${ }^{27,43,44}$. Here the viability and integrity of $R$. palustris grown on landfill leachate as culture medium were successfully assayed (Fig. 5), which was not previously reported and very important in the exhibited a red fluorescence intensity (Fig.5b). When the mixture of fresh and heat-killed cells was measured using FDA-PI double-fluorescent, the live cells (R1) were almost equivalent to the dead cells (R2) (Fig.5c).

The live $R$. palustris grown on landfill leachate with time course

Figure 6 indicated the total and live cell densities as well as the ratio of live cells using FDA$\mathrm{PI}$ double-fluorescent staining in conjunction with flow cytometer. The results showed that the live cell densities of $R$. palustris were almost same to total cell densities of $R$. palustris during the period of $96 \mathrm{~h}$ and the highest proportion of live cells of $99.4 \%$ was obtained at $72 \mathrm{~h}$.

culture of the live cells of $R$. palustris as bacterial manure.

Generally many studies paid attention on the removals of TOC and TN from landfill leachate, but less information concentrated on the growth and live cells of PSB. As a typical bacterial strain of PSB, R. palustris can be used in many areas 


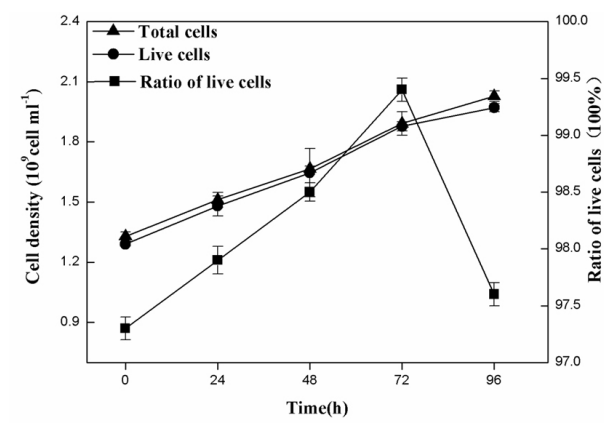

Fig. 6. The live $R$. palustris grown on landfill leachate with time course.

such as bacterial manure ${ }^{7}$, food coloring agent, precursor of vitamin $A$ in food and animal feed, $\beta$-carotene and astaxanthin in industry, and additives to porphyrin ${ }^{8,9}$, so the efficient culture of $R$. palustris is very important in the resource utilization of organic waste water. Here both the treatment of landfill leachate and the growth of $R$. palustris were investigated together, which is benefit to culture $R$. palustris as bacterial manure with the efficient utilization of landfill leachate as culture medium.

\section{CONCLUSION}

Alkaline condition could cause the flocculation and the removals of TOC and TN from landfill leachate. The growth of $R$. palustris in landfill leachate could be much improved by adding phosphorus. With the increase of inoculation ratio, both the growth of $R$. palustris and the removals of TOC and TN from landfill leachate were all enhanced. $R$. palustris maintained the good viability and integrity during the culture period of $96 \mathrm{~h}$, which was detected with the method of FDAPI double-fluorescent staining. This study revealed a biotechnology for the resource utilization of landfill leachate to culture $R$. palustris as bacterial manure.

\section{ACKNOWLEDGMENTS}

This study was financially supported by National Natural Science Foundation of China (No. 21177009) and Special Foundation of Doctoral Program, Ministry of Education, the People's Republic of China (No.20120006110001).

\section{REFERENCES}

1. Kale, D. K. and P. D. Anthappan . Sustainable Treatment of Wastewater using Effective Microorganisms. Journal of Pure and Applied Microbiology, 2016; 6(1):333-338.

2. $\quad W u$, L., Li, Z., Zhao, C., Liang, D.W., Peng, Y.Z. A novel partial-denitrification strategy for post-anammox to effectively remove nitrogen from landfill leachate. Sci. Total Environ. 2018; 633: 45-751.

3. Krcmar, D., Tenodi, S., Grba, N., Kerkez, D., Watson, M., Ronevi, S.,Dalmacija, B. Preremedial assessment of the municipal landfill pollution impact on soil and shallow groundwater in Subotica, Serbia. Sci. Total Environ. 2018; 615:1341-1354.

4. Merugu, R., Rudra, M. P. P., Thirupathaiah, A., Girisham, S., Reddy, S.M. Chromate reduction by a purple non sulphur phototrophic bacterium rhodobacter capsulatus KU002 isolated from tannery rffluents. Journal of Pure and Applied Microbiology. 2011; 5(2):1027-1029.

5. Sniffen, K. D., Sales, C. M., \& Olson, M. S. The fate of nitrogen through algal treatment of landfill leachate. Algal Research, 2018; 30:50-58.

6. Chen, W. T., Zhang, H. G., Luo, D. G., Chen, Y. H. Research on Treating Acid Wastewater Containing Heavy Metals by Sulfate-Reducing Bacteria. J Pure Appl Microbiol, 2103; 7(3):2079-2083.

7. Zhou, Q., Zhang, P., Zhang, G. Biomass and pigments production inphotosynthetic bacteria wastewater treatment: effects of light sources. Bioresour. Technol, 2015; 179:505-509.

8. Aksu, Z., Eren, A.T. Carotenoids production by the yeast Rhodotorula mucilaginosa: use of agricultural wastes as a carbon source. Process Biochem, 2005; 40:2985-2991.

9. Tamiaki, H., Matsunaga, S., Taira, Y., Wada, A., Kinoshita, Y., Kunieda, M. Synthesis of zinc 20-substituted bacteriochlorophyll-d analogs and their self-aggregation. Tetrahedron Lett; 2014; 55:33513354.

10. Hashimoto, S., Furukawa, K. Nutrient removal from secondary effluent by filamentous algae. J. Ferment. Bioeng, 1989; 67:62-69.

11. Raymond, J., Siefert, J.L., Staples, C.R., Blankenship, R.E. The natural history of nitrogen fixation. Mol. Biol. Evol, 2004; 21:541-554.

12. Sasikala, C., Ramana, C.V. Biotechnological potentials of anoxygenic phototrophic bacteria. I. production of single-cell protein, vitamins, ubiquinones, hormones, and enzymes and use in waste treatment. Adv. Appl. Microbiol, 1995, 41:173-226.

13. Koh, R.H., Song, H.G. Effects of application of Rhodopseudomonas sp. On seed germination and growth of tomato under axenic conditions. J. Microbiol. Biotechnol, 2007; 17:1805-1810.

14.. Rautter, J., Lendzian, F., Lubitz, W., Wang, S., Allen, J.P. Comparative study of reaction centers from photosynthetic purple bacteria: electron paramagnetic resonance and electron nuclear double resonance spectroscopy. Biochemistry, 1994; 33:12077-12084.

15. Chitapornpan, S., Chiemchaisri, C., Chiemchaisri, W., Honda, R., Yamamoto, K. Organic carbon recovery and photosynthetic bacteria population in an anaerobic membrane photo-bioreactor treating food processing wastewater. Bioresour. Technol, 2013; 141:65-74. 
16. Ela, E., Ufuk, G., Meral, Y., Inci, E. Photosynthetic bacterial growth and productivity under continuous illumination or diurnal cycles with olive mill wastewater as feedstock. Int. J. Hydrogen Energ, 2010; 35:52935300.

17. Prachanurak, P., Chiemchaisri, C., Chiemchaisri, W., Yamamotob, K. Biomass production from fermented starch wastewater in photo-bioreactor with internal overflow recirculation. Bioresour. Technol, 2014; 165:129-136.

18. Izu, K., Nakajima, F., Yamamoto, K., Kurisu, F. Aeration conditions affecting growth of purple nonsulfur bacteria in an organic wastewater treatment process. Syst. Appl. Microbiol, 2001; 24:294-302.

19. Siefert, E., Irgens, R.L., Pfennig, N. Phototrophic purple and green bacteria in a sewage treatment plant. Appl. Environ. Microbiol, 1978; 35:38-44.

20. Zhou, Q., Zhang, P., Zhang, G. Biomass and carotenoid production in photosynthetic bacteria wastewater treatment: effects of light intensity. Bioresour. Technol, 2014; 171:330-335.

21. Zhou, Q., Zhang, P., Zhang, G. Biomass and pigments production in photosynthetic bacteria wastewater treatment: effects of light sources. Bioresour. Technol, 2015; 190:196-200.

22. Liao, B.Q., Lin, H.J., Langevin, S.P., Gao, W.J., Leppard, G.G. Effects of temperature and dissolved oxygen on sludge properties and their role in bioflocculation and settling. Water Res, 2011; 45:2509-2520.

23. Meng, F., Yang, A., Zhang, G., Wang, H. Effects of dissolved oxygen concentration on photosynthetic bacteria wastewater treatment: Pollutants removal, cell growth and pigments production. Bioresour. Technol, 2017; 241:993-997.

24. Yadav, T.C., Khardenavis, A.A., Kapley, A. Shifts in microbial community in response to dissolved oxygen levels in activated sludge. Bioresour. Technol, 2014; 165:257-264.

25. Xu, Q.Q., Yan, H., Liu, X.L., Lv, L., Yin, C.H., Wang, P. Growth performance and meat quality of broiler chickens supplemented with Rhodopseudomonas palustris in drinking water. Asian. Austral. J. Anim, 2012; 25:682-689.

26. Breeuwer, P., Abee, T. Assessment of viability of microorganisms employing fluorescence techniques. Int. J. Food Microbiol, 2000; 55:193-200.

27. Bunthof, C.J., Bloemen, K., Breeuwer, P., Rombouts, F.M., Abee, T. Flow cytometric assessment of viability of lactic acid bacteria. Appl. Environ. Microbiol, 2001; 67:2326-2335.

28. Rault, A., Beal, C., Ghorbal, S., Ogier, J.C., Bouix, M. Multiparametric flow cytometry allows rapid assessment and comparison of lactic acid bacteria viability after freezing and during frozen storage. Cryobiology, 2007; 55:35-43.

29. Qin, L., Liu, Q., Meng, Q., Fan, Z., He, J., Liu, T., Zhang, $G$. Anoxic oscillating MBR for photosynthetic bacteria harvesting and high salinity wastewater treatment. Bioresour. Technol, 2017; 224:69-77.

30. Kulikowska, D., Klimiuk, E. The effect of landfill age on municipal leachate composition. Bioresour. Technol, 2008; 99:5981-5985.
31. Getha, K., Vikineswary, S., Chong, V.C. Isolation and growth of the phototrophic bacterium $R$. palustris strain B1 in sago-starch-processing wastewater. World J. Microbiol. Biotechnol, 1998; 14:505-511.

32. Bakar, Abdul Fattah Abu, and A. A. Halim . Treatment of automotive wastewater by coagulation-flocculation using poly-aluminum chloride (PAC), ferric chloride ( $\mathrm{FeCl} 3)$ and aluminum sulfate (alum). American Institute of Physics. 2013.

33. Li, W., Hua, T., Zhou, Q., Zhang, S., Li, F. Treatment of stabilized landfill leachate by the combined process of coagulation/flocculation and powder activated carbon adsorption. Desalination, 2010; 264:56-62.

34. Erabee, I.K., Ahsan, A., Jose, B., Arunkumar, T., Sathyamurthy, R., Idrus, S., Daud, N.N. Effects of electric potential, $\mathrm{NaCl}, \mathrm{pH}$ and distance betweenelectrodes on efficiency of electrolysis in landfill leachate treatment. J. Environ. Sci. Heal. A, 2017; 52:735-741.

35. Sawayama, S. , Tsukahara, K. , \& Yagishita, T. Organic acid consumption of phototrophic bacteria in a lighted upflow anaerobic sludge blanket reactor. Journal of Bioscience \& Bioengineering, 2000; 90(3):241-246.

36. Wei, Z., Zhang, G.M. Effects of trace elements on photosynthetic bacteria growth in wastewater. Harbin Ins. Tech, 2012; 44:52-55.

37.T sygankov, A.S., Serebryakova, L.T., Sveshnikov, D.A., Rao, K.K., Gogotov, I.N., Hall, D.O. Hydrogen photoproduction by three different nitrogenases in wole cells of Anabaena variabilis and the dependence on pH. Int. J. Hydrogen Energy, 1997; 22:859-867.

38. Buche, A., Ellis, G., Ramirez, J.M. Probing the binding site of 800-nm bacteriochlorophyll in the memebranelinked LH2 protein of Rhodobacter capsulatus by local unfolding and chemical modification. Eur. J. Biochem, 2001; 26:2792- 2800.

39. Fraser, N.J., Dominy, P.J., Ucker, B., Simonin, I., Scheer, H., Cogdell, R.J. Selective release, removal, and reconstitution of bacteriochlorophyll a molecules into the b800 sites of Ih2 complexes from Rhodopseudomonas acidophila 10050. Biochemistry, 1999; 38:9684-9692.

40. Xie, H.G., Wang, S.F., Chu, R. Treatment of brewery wastewater with photosynthetic bacteria. Ind. Water \& Wastewater, 2006; 37:38-40.

41. Lu, H., Zhang, G., Lu, Y., Zhang, Y., Li, B., Cao, W. Using co-metabolism to accelerate synthetic starch wastewater degradation and nutrient recovery in photosynthetic bacterial wastewater treatment technology. Environ. Technol, 2016; 37:775-784.

42. Sheeba, K.N. Experimental study on adsorption of malachite green in simulated and real effluent by bio-based adsorbents. Int. J. Green Energy, 2015; 12:1189-195.

43. Bensch, G., Ruger, M., Wassermann, M., Weinholz, S., Reichl, U., Cordes, C., Flow cytometric viability assessment of lactic acid bacteria starter cultures produced by fluidized bed drying. Appl. Microbiol. Biotechnol, 2014; 98:4897-909.

44. He, S., Hong, X., Huang, T., Zhang, W., Zhou, Y., Wu, L. Rapid quantification of live/dead lactic acid bacteria in probiotic products using high-sensitivity flow cytometry. Methods Appl. Fluoresc, 2017; 5:024002. 